\title{
Effects of the Selected Combination of Boron and Zinc in Presence of Different Doses of NPK Fertilizers on Yield and Quality of Okra Seed
}

\author{
Md. Habibur Rahman ${ }^{1}$, Md. Abdus Sattar ${ }^{2}$, Md. Razzab Ali ${ }^{3}$, Tanjila Nasreen Trina ${ }^{4}$, \\ Mohammed Hossain Sarker \\ ${ }^{1}$ Regional Agricultural Research Station, Bangladesh Agricultural Research Institute, Cumilla, Bangladesh \\ ${ }^{2}$ Farm Division, Bangladesh Agricultural Research Institute, Gazipur, Bangladesh \\ ${ }^{3}$ Olericulture Division, Bangladesh Agricultural Research Institute, Gazipur, Bangladesh \\ ${ }^{4}$ Bangladesh Institute of Nuclear Agriculture, BINA Substation, Rangpur, Bangladesh \\ ${ }^{5}$ Farm Division, Bangladesh Agricultural Research Institute, Gazipur, Bangladesh
}

Email address:

rahmanag@yhoo.com (Md. H. Rahman), sattar72@gmail.com (Md. A. Sattar), razzab321@gmail.com (Md. R. Ali), trina.gpb@gmail.com (T. N. Trina), hossain.agro@yahoo.com (M. H. Sarker)

\section{To cite this article:}

Md. Habibur Rahman, Md. Abdus Sattar, Md. Razzab Ali, Tanjila Nasreen Trina, Mohammed Hossain Sarker. Effects of the Selected Combination of Boron and Zinc in Presence of Different Doses of NPK Fertilizers on Yield and Quality of Okra Seed. American Journal of Biological and Environmental Statistics. Vol. 7, No. 1, 2021, pp. 19-28. doi: 10.11648/j.ajbes.20210701.13

Received: December 11, 2020; Accepted: February 15, 2021; Published: March 10, 2021

\begin{abstract}
The experiment was carried out at the Horticulture Research Centre of the Bangladesh Agricultural Research Institute, Joydebpur, Gazipur, during April to September 2013to investigate the effects of boron, zinc, and NPK on the yield and quality of okra seed subjected to improve the micronutrient management practices on quality seed production. There were four levels of boron and zinc $(0 \mathrm{~kg} \mathrm{~B}+0 \mathrm{~kg} \mathrm{Zn} / \mathrm{ha}, 1.5 \mathrm{~kg} \mathrm{~B}+2.0 \mathrm{~kg} \mathrm{Zn} / \mathrm{ha}, 2.0 \mathrm{~kg} \mathrm{~B}+4.0 \mathrm{~kg} \mathrm{Zn} / \mathrm{h}$ and $2.5 \mathrm{~kg} \mathrm{~B}+6.0 \mathrm{~kg}$ $\mathrm{Zn} / \mathrm{ha}$ ) and three levels of NPK fertilizers (50\% less than the recommended dose of NPK, recommended dose of NPK and $50 \%$ more than the recommended dose of NPK). Different selected levels of boron and zinc application separately and in combination with NPK fertilizers influenced the yield and quality of okra seed. Application of $2 \mathrm{~kg} \mathrm{~B} / \mathrm{ha}$ and $4 \mathrm{~kg} \mathrm{Zn} / \mathrm{ha}$ in combination with the recommended dose of NPK fertilizers demonstrated the highest seed yield (2.69 t/ha), seed germination (97.00\%), seedling vigour index (2845.01) and seed protein content (19.89\%) whereas the lowest seed yield (1.93 t/ha.), seed germination (78.50\%), seedling vigour index (1953.86) and seed protein content $(16.30 \%)$ were found from $0 \mathrm{~kg} \mathrm{~B} / \mathrm{ha}$ and $0 \mathrm{~kg}$ $\mathrm{Zn} / \mathrm{ha}$ with $50 \%$ less than the recommended dose of NPK application. Maximum yield and good quality of okra seed can be obtained from the application of $2 \mathrm{~kg} \mathrm{~B}$ and $4 \mathrm{~kg} \mathrm{Zn} / \mathrm{ha}$, in combination with the recommended dose of NPK fertilizers.
\end{abstract}

Keywords: Boron, Zinc, NPK, Yield Attributes, Quality Seed

\section{Introduction}

Okra (Abelmoschusesculentus L.) is a popular nutritious vegetable in Bangladesh which belongs to the Malvaceae family and locally known as "Dherosh" or "Bhindi. It is grown in the summer season when vegetables are scanty in the market [1]. The green tender fruits of okra contain $1.76 \mathrm{~g}$ protein, $8.73 \mathrm{~g}$ carbohydrate, $1.1 \mathrm{~g}$ fibre, $88 \mathrm{IU}$ Vitamin A, 9.8 $\mathrm{mg}$ Vitamin $\mathrm{C}$ and $116 \mathrm{mg} \mathrm{Ca}$ in every $100 \mathrm{~g}$ of okra [2]. Moreover, the seed of okra is a good source of protein [3].
Successful crop production depends on quality seed. Most of the farmer uses their own seeds which are in most cases of inferior quality and use of poor quality seeds is responsible for low yield in Bangladesh [4]. By using quality seed, production can be increased up to $25-50 \%[5,6]$. So good quality okra seed is very necessary for the farmers of Bangladesh. There are several major factors viz., maintenance of genetic purity, prevailing agro-ecological 
conditions, fertilizer management especially micronutrients, pest and disease infestation, adequate cultural management affect good quality seed production. Among the micronutrients, the deficiency of boron and zinc in the soils of Bangladesh was most prevalent and the deficiency of Mo, $\mathrm{Cu}$ and $\mathrm{Mn}$ had occasionally been reported [7-9]. Boron and zinc play an significant role directly and indirectly in improving the yield and quality of okra seed production [10]. Male sterility and pistil sterility occurs due to boron deficiency [11, 12]. Pollen tube growth, fruit set and development are affected by boron [13, 14]. Boron acts for carbohydrate metabolism, cell division, protein formation, increase the brightness of leaf, flower and fruit, keeps pollen healthy and viable, helps seed production and prevents sterility of seed. Zinc mainly act as the metal component of a series of enzymes. Zinc deficiency is thought to restrict RNA synthesis, which in turn inhibits protein synthesis [15]. Zinc is also involved in aux in production and flower and fruit setting [16]. It also plays important role in chlorophyll formation, cell division, meristem tic activity of tissue expansion and formation of the cell wall. It increases photosynthesis and translocation of food materials. The function of micronutrients in the reproductive process as well as seed production of okra is very important. Zinc application also helps in increasing the uptake of nitrogen and potassium. Nitrogen (N) plays significant role on leaf growth and formation of proteins and chlorophyll. Phosphorus (P) contributes to root, flower and fruit development. Potassium (K) contributes to stem and root growth and the synthesis of proteins $[17,18]$. Potassium imparts vigour and disease resistance to the plant and plays an important role in crop productivity [19]. Information about the combined effects of boron, zinc and NPK application on yield and quality of okra is inadequate in Bangladesh. Considering the above facts, the present study was carried out to evaluate the integrated performance of boron, zinc and NPK for yield and quality of okra seed and therefore determine the optimum doses of B, Zn and NPK association on yield and quality of okra seed.

\section{Methods and Materials}

\subsection{Experimental Site and Soil}

The experiment was conducted during April to September 2013 at the Vegetable Research Field, Horticulture Research Centre, Bangladesh Agricultural Research Institute, Joydebpur, Gazipur. The experimental site located at Gazipur $\left(24^{\circ} 0^{\prime} 13^{\prime \prime} \mathrm{N}\right.$ latitude; $90^{\circ} 25^{\prime} 0^{\prime \prime} \mathrm{E}$ longitude) at an elevation of $8.4 \mathrm{~m}$ above sea level which is characterized by a moist monsoon subtropical climate. Terrace soils of the location belonging to the Chhiata Series (soil taxonomy: UdicRhodustalf). The experimental site has a typical tropical and sub-tropical continental monsoon climatic condition. It is characterized by comparatively high monsoon rainfall, high humidity and high temperature [20]. The mean air temperature is $29.91^{\circ} \mathrm{C}$. The mean precipitation is 162.36 $\mathrm{mm}$, with humidity approximately $87.01 \%$ occurring from April to September. Before starting the experiment, the initial soil sample $(0-15 \mathrm{~cm})$ of the experiment was analyzed and the chemical properties are presented in Table 1.

Table 1. Result of the chemical analysis of soil sample ofthe experiment field at Horticulture Research Centre.

\begin{tabular}{|c|c|c|c|c|c|c|c|c|}
\hline \multirow{2}{*}{ Factor } & \multirow{2}{*}{ pH } & \multirow{2}{*}{ OM (\%) } & \multirow{2}{*}{ Total N (\%) } & \multirow{2}{*}{$\mathrm{K}(\mathrm{meq} / \mathbf{1 0 0 g})$} & $\mathbf{P}$ & $\mathbf{S}$ & $\mathrm{Zn}$ & B \\
\hline & & & & & \multicolumn{4}{|l|}{$\mu \mathrm{g} \cdot \mathrm{g}^{-1}$} \\
\hline Gazipur & 6.3 & 1.39 & 0.086 & 0.10 & 14 & 14 & 0.72 & 0.24 \\
\hline Critical level & $5.5-6.5$ & $-{ }^{a}$ & 0.12 & 0.12 & 7 & 10 & 0.60 & 0.20 \\
\hline Interpretation $^{\mathrm{b}}$ & Slightly acidic & Low & Very low & Low & Medium & Medium & Low & Low \\
\hline
\end{tabular}

a $=$ not known

${ }^{\mathrm{b}}$ Fertilizer Recommendation Guide [21].

\subsection{Land Preparation, Treatments, Design and Layout}

The experimental land was opened by using tractor operated disc plough. After that, the land was prepared thoroughly by tractor operated rotavator followed by laddering and levelling. The experiment was carried with 12 treatment combinations comprising four levels of boron and zinc $(0 \mathrm{~kg} \mathrm{~B}+0 \mathrm{~kg} \mathrm{Zn} / \mathrm{ha}, 1.5 \mathrm{~kg} \mathrm{~B}+2.0 \mathrm{~kg} \mathrm{Zn} / \mathrm{ha}, 2.0 \mathrm{~kg}$ $\mathrm{B}+4.0 \mathrm{~kg} \mathrm{Zn} / \mathrm{h}$ and $2.5 \mathrm{~kg} \mathrm{~B}+6.0 \mathrm{~kg} \mathrm{Zn} / \mathrm{ha})$ and three levels of NPK fertilizer $(50 \%$ less than the recommended dose, Recommended dose and 50\% more than the recommended dose of NPK). The experiment was laid out in Randomized Complete Block Design with two factorial concepts having 3 replications. The unit plot size was $4 \mathrm{~m} \times$ $2.4 \mathrm{~m}$, where 40plants were accommodated in each plot at a spacing of $60 \mathrm{~cm} \times 40 \mathrm{~cm}$. Two adjacent unit plots were separated by $70 \mathrm{~cm}$ space and there was $100 \mathrm{~cm}$ space between the blocks.

\subsection{Application of Fertilizer}

As per Fertilizer Recommendation Guide of BARC, the recommended doses of NPK fertilizers for okra are 10 tons of cow dung, $200 \mathrm{~kg}$ urea, $250 \mathrm{~kg}$ TSP, $150 \mathrm{~kg} \mathrm{MoP,} 100 \mathrm{~kg}$ Gypsum, $10 \mathrm{~kg}$ zinc sulphate, and $7 \mathrm{~kg}$ boric acid/ha (FRG, BARC. 2005) [21]. The sources of N, P, K, S, B and Zn were urea, TSP, MoP, gypsum, boric acid and zinc sulphate, respectively. For each fertilizer treatment combination, the boron, zinc and NPK dose was calculated and applied timely.

\subsection{Seed Sowing and Agronomic Practice}

BARI Dharosh-1 variety was used in this research work. Three seeds were shown per pit maintaining plant to plant distance $40 \mathrm{~cm}$. At 5-6 leaves stage only one healthy seedling 
was kept in one pit and rest two seedlings were removed. Weedings were done regularly; fungicide Secure 600 wg@ $0.2 \%$ was sprayed at an interval of 10 days start at flowering stage. At fruit bearing stage pod borer and aphid was controlled by spraying Karate @ $0.2 \%$ at 10 days interval. Irrigation and other management practices were done as per requirement. Seeds were collected from matured fruits.

\subsection{Data Collection Procedure}

\subsubsection{Growth and Yield Data}

Randomly ten plants were selected from a treatment plot for taking data of plant height, number of fruits per plant, length of fruit, girth of fruit, number of seeds per fruit, 1000seed weight and seed yield per hectare. Seeds were collected manually and dried in sun until it reached about $8 \%$ moisture content. (Measured by Digital moisture meter, model-750).

\subsubsection{Germination and Seedling Vigour Index}

Germination test was carried out through sand culture. Four hundred pure seeds were randomly selected from each sample. The selected seeds were sown in a plastic pot filled with moist sand. The sand was sterilized through sunburn before using in germination test. The seeds were soaked for 12 hours in water before sowing for quick germination. First, second and last counting of germination were made after 4,8 and 12 days of germination period respectively. Only the normal seedlings were included in the computation of germination percentage. Percentage of germination was determined by using the following formula as suggested by Agrawal [22]:

\section{$\%$ Germination=Number of normal seedlings $/$ Number of} seeds sown $\mathrm{x} 100$

After 14 days of setting germination, 10 seedlings were randomly selected for seedling vigour index test. Altogether 40 seedlings were selected from each sub-sample. Shoot length $(\mathrm{cm})$ and root length $(\mathrm{cm})$ of the seedlings were recorded and mean values of the two parameters were computed. Vigour index was computed following the formula as suggested by Abdul-Baki and Anderson [23], where,

Seedling vigour index $=[$ Mean shoot length $(\mathrm{cm})+$ Mean root length $(\mathrm{cm})] \mathrm{x}$ Germination $(\%)$.

\subsubsection{Seed Protein Content}

Seed protein content was analyzed following the method described by Lowery et al. [24]. One gram of each seed sample was crushed after soaking in distilled water for 4 hours then $100 \mathrm{ml}$ of distilled water was added to it and was defatted by adding diethyl ether. $0.4 \mathrm{ml}$ of the supernatant was pipetted in a test tube containing freshly prepared FolinCiocalteau Phenol reagent. Then the mixture of these three solutions was shaken and allowed to stand for 30 minutes. Spectrophotometer at $750 \mathrm{~nm}$ was used to measure optical density. Bovine Serum albumin was used to plot a standard curve for the estimation of protein content in the solution. Seed protein content was determined quarterly with three replication.

\subsubsection{Seed Boron Content}

Boron content was determined by Curcumin method [25]. A $0.25 \mathrm{ml}$ seed filtrate was taken in a plastic bottle; $2.0 \mathrm{ml}$ of Curcumin in HOAC was added and thoroughly mixed. $0.5 \mathrm{ml}$ of conc. $\mathrm{H}_{2} \mathrm{SO}_{4}$ was added and thoroughly mixed and was allowed to stand at least 35 minutes for cooling. Then $15 \mathrm{ml}$ of methanol solution (3:2) was added and mixed thoroughly. After 15 minutes, the spectrophotometer reading was recorded at $555 \mathrm{~nm}$. The boron value (ppm) was determined by the following equation:

$$
\text { Boron }(\mathrm{ppm})=\mathrm{Y} \times \mathrm{Abs}(\mathrm{X}) \mathrm{x} \mathrm{f}
$$

Where $\mathrm{Y}=\mathrm{df}=100 / 0.25 \times(1) \times \mathrm{ml} / 0.5=800$

Where $100=$ Sample volume up to $100 \mathrm{ml}$

$\mathrm{F}=6.25$ (From standard curve)

$0.25 \mathrm{ml}=$ filtrate taken, $0.5 \mathrm{~g}=$ seed sample

\subsubsection{Seed Zinc Content}

The seed sample was oven-dried and analyzed for $\mathrm{Zn}$ by using an Absorption Spectrophotometer (AAS) according to Rahayu et al. [26].

\subsection{Statistical Analysis}

The collected data were compiled and tabulated, which were subjected to statistical analyses following standard methodology and the mean differences were adjudged by Duncan's Multiple Range Test [27].

\section{Results}

\subsection{Plant Height}

The height of plant varied with soil application of boron and zinc levels. It ranged from $159.59 \mathrm{~cm}$ to $181.74 \mathrm{~cm}$ (Table 2). Similarly, plant height was also influenced by different levels of NPK. It was as high as $179.33 \mathrm{~cm}$ in $50 \%$ more than the recommended doses of NPK and was as low as $167.53 \mathrm{~cm}$ in $50 \%$ less than the recommended dose of NPK (Table 3). Significant variation was found among the treatment combinations in case of plant height. The tallest plants $(188.56 \mathrm{~cm})$ were produced with $2.5 \mathrm{~kg} \mathrm{~B}+6.0 \mathrm{~kg}$ $\mathrm{Zn} / \mathrm{ha}$ and $50 \%$ more than the recommended dose of NPK application, which was statistically similar with treatment 2.0 $\mathrm{kg} \mathrm{B}+4.0 \mathrm{~kg} \mathrm{Zn} / \mathrm{ha}$ and recommended dose of NPK (186.40 $\mathrm{cm})$ on the other hand, the lowest plant height $(153.81 \mathrm{~cm})$ was recorded from $0 \mathrm{~kg} \mathrm{~B}+0 \mathrm{~kg} \mathrm{Zn} / \mathrm{ha}$ and $50 \%$ less than the recommended dose of NPK, $0 \mathrm{~kg} \mathrm{~B}+0 \mathrm{~kg} \mathrm{Zn} / \mathrm{ha}$ and recommended dose of NPK $(160.51 \mathrm{~cm})$ both were statistically similar (Table 4). 
Table 2. Main effect of boron and zinc on yield contributing characters of okra seed.

\begin{tabular}{llllllll}
\hline Treatments & Plant height (cm) & $\begin{array}{l}\text { No. of } \\
\text { fruits/Plant }\end{array}$ & $\begin{array}{l}\text { Fruit length } \\
(\mathbf{c m})\end{array}$ & $\begin{array}{l}\text { Fruit girth } \\
\text { (cm) }\end{array}$ & $\begin{array}{l}\text { No. of } \\
\text { seeds/fruit }\end{array}$ & $\begin{array}{l}\text { 1000- seed } \\
\text { wt. (g.) }\end{array}$ & $\begin{array}{l}\text { Seed yield } \\
\text { (t/ha.) }\end{array}$ \\
\hline $\mathrm{B}_{0} \mathrm{Zn}_{0}$ & $159.59 \mathrm{~b}$ & $17.80 \mathrm{c}$ & $17.10 \mathrm{~b}$ & $1.67 \mathrm{~b}$ & $51.85 \mathrm{c}$ & $58.23 \mathrm{c}$ & $1.98 \mathrm{c}$ \\
$\mathrm{B}_{1.5} \mathrm{Zn}_{2.0}$ & $175.63 \mathrm{a}$ & $18.40 \mathrm{~b}$ & $18.26 \mathrm{a}$ & $1.70 \mathrm{~b}$ & $54.20 \mathrm{~b}$ & $59.31 \mathrm{~b}$ & $2.18 \mathrm{~b}$ \\
$\mathrm{~B}_{2.0} \mathrm{Zn}_{4.0}$ & $181.74 \mathrm{a}$ & $19.22 \mathrm{a}$ & $19.07 \mathrm{a}$ & $1.88 \mathrm{a}$ & $58.91 \mathrm{a}$ & $61.04 \mathrm{a}$ & $2.52 \mathrm{a}$ \\
$\mathrm{B}_{2.5} \mathrm{Zn}_{6.0}$ & $181.25 \mathrm{a}$ & $19.10 \mathrm{a}$ & $18.97 \mathrm{a}$ & $1.85 \mathrm{a}$ & $58.12 \mathrm{a}$ & $60.87 \mathrm{a}$ & $2.50 \mathrm{a}$ \\
$\mathrm{Level} \mathrm{of} \mathrm{significance}$ & $* *$ & $*$ & $* *$ & $*$ & $* *$ & $*$ & $* *$ \\
$\mathrm{CV}(\%)$ & 4.14 & 2.25 & 3.62 & 2.28 & 2.23 & 0.65 & 4.38 \\
\hline
\end{tabular}

Note: $\mathrm{B}_{0}=0 \mathrm{~kg}$ boron/ha, B $1.5=1.5 \mathrm{~kg}$ boron/ha, B $2.0=2 \mathrm{~kg}$ boron $/ \mathrm{ha}$, B $2.5=2.5 \mathrm{~kg}$ boron $/ \mathrm{ha}, \mathrm{Zn} 0=0 \mathrm{~kg}$ zinc $/ \mathrm{ha}, \mathrm{Zn} 2.0=2 \mathrm{~kg}$ zinc $/ \mathrm{ha}, \mathrm{Zn} 4.0=4 \mathrm{~kg}$ zinc $/ \mathrm{ha}, \mathrm{Zn}$ ${ }_{6.0}=6 \mathrm{~kg}$ zinc/ha.

Table 3. Main effect of NPK on yield contributing characters of okra seed.

\begin{tabular}{llllllll}
\hline Treatment & $\begin{array}{l}\text { Plant height } \\
(\mathbf{c m})\end{array}$ & $\begin{array}{l}\text { No. of fruits/ } \\
\text { Plant }\end{array}$ & $\begin{array}{l}\text { Fruit length } \\
(\mathbf{c m})\end{array}$ & $\begin{array}{l}\text { Fruit girth } \\
(\mathbf{c m})\end{array}$ & $\begin{array}{l}\text { No. of } \\
\text { seeds/Fruit }\end{array}$ & $\begin{array}{l}\mathbf{1 0 0 0} \text {-seed } \\
\text { wt. (g.) }\end{array}$ & $\begin{array}{l}\text { Seed yield } \\
\text { (t/ha.) }\end{array}$ \\
\hline NPK $50 \%<$ RD & $167.53 \mathrm{~b}$ & $18.37 \mathrm{~b}$ & $17.73 \mathrm{~b}$ & $1.69 \mathrm{~b}$ & $55.10 \mathrm{~b}$ & $59.42 \mathrm{~b}$ & $2.23 \mathrm{~b}$ \\
NPK RD & $176.80 \mathrm{a}$ & $19.05 \mathrm{a}$ & $18.88 \mathrm{a}$ & $1.83 \mathrm{a}$ & $56.85 \mathrm{a}$ & $60.33 \mathrm{a}$ & $2.40 \mathrm{a}$ \\
NPK $50 \%>\mathrm{RD}$ & $179.33 \mathrm{a}$ & $18.46 \mathrm{a}$ & $18.45 \mathrm{ab}$ & $1.79 \mathrm{a}$ & $55.36 \mathrm{~b}$ & $59.84 \mathrm{ab}$ & $2.26 \mathrm{~b}$ \\
Level of significance & $* *$ & $* *$ & $* *$ & $*$ & $* *$ & $* *$ & $* *$ \\
CV (\%) & 4.14 & 2.25 & 3.62 & 2.28 & 2.23 & 0.65 & 4.38 \\
\hline
\end{tabular}

Note: NPK RD=Recommended dose of NPK fertilizers (Urea $=200 \mathrm{~kg}, \mathrm{TSP}=250 \mathrm{~kg}, \mathrm{MP}=150 \mathrm{~kg}$ ). In a column, the figures having similar letter (s) do not differ significantly at 0.05 level of probability, ${ }^{*}=$ Significant at 0.01 level, ${ }^{*}=$ Significant at 0.05 level

\subsection{Number of Fruits Per Plant}

The variation was found wide regarding the number of fruits per plant as to the different levels of boron and zinc applied to soil. The highest number of fruits per plant (19.22) was observed with $2.0 \mathrm{~kg} \mathrm{~B}+4.0 \mathrm{~kg} \mathrm{Zn} / \mathrm{ha}$ and $2.5 \mathrm{~kg} \mathrm{~B}+6$ $\mathrm{kg} \mathrm{Zn/ha} \mathrm{(19.10)} \mathrm{those} \mathrm{were} \mathrm{statistically} \mathrm{equal} \mathrm{and} \mathrm{the} \mathrm{lowest}$ (17.80) was found from no boron and zinc application (Table 2). This parameter was also significantly influenced due to the NPK levels. It ranged from 18.37 to 19.05 (Table 3). Fruits per plant was significantly influenced by the combined effect of boron and zinc with NPK. The highest number of fruits per plant (20.00) was obtained from $2.0 \mathrm{~kg} \mathrm{~B} \mathrm{\&} 4.0 \mathrm{~kg}$ $\mathrm{Zn} / \mathrm{ha}$ with the recommended dose of NPK, which was statistically similar with $2.5 \mathrm{~kg} \mathrm{~B}+6 \mathrm{~kg} \mathrm{Zn} / \mathrm{ha}$ and recommended dose of NPK (19.50) and $2.5 \mathrm{~kg} \mathrm{~B}+6 \mathrm{~kg}$ $\mathrm{Zn} / \mathrm{ha}$ and $50 \%$ more than the recommended dose of NPK (19.00), while the lowest (17.50) was recorded with $0 \mathrm{~kg} \mathrm{~B}+$ $0 \mathrm{~kg} \mathrm{Zn} / \mathrm{ha}$ and $50 \%$ less than the recommended dose of NPK followed by $0 \mathrm{~kg} \mathrm{~B}+0 \mathrm{~kg} \mathrm{Zn} / \mathrm{ha}$ and $50 \%$ more than the recommended dose of NPK (17.70) both were statistical similar (Table 4).

\subsection{Fruit Length and Fruit Girth}

Fruit length was found significantly different due to different levels of boron and zinc used as soil application. The highest fruit length $(19.07 \mathrm{~cm})$ was recorded from $2.0 \mathrm{~kg}$ $\mathrm{B}+4.0 \mathrm{~kg} \mathrm{Zn} / \mathrm{ha}$ followed by $2.5 \mathrm{~kg} \mathrm{~B}+6.0 \mathrm{~kg} \mathrm{Zn} / \mathrm{ha}(18.97$ $\mathrm{cm})$, while it was the lowest $(17.10 \mathrm{~cm})$ in without boron and zinc application (Table2). Besides the main effect, NPK significantly influenced the length of fruit. The highest fruit length $(18.88 \mathrm{~cm})$ was found with the recommended dose of
NPK and the lowest fruit length was observed in 50\% less than the recommended dose of NPK $(17.73 \mathrm{~cm})$ (Table 3). Distinct variation was observed among the combinations of boron, zinc and NPK as to the length of fruit. Maximum fruit length $(19.55 \mathrm{~cm})$ was recorded with the application of $2.0 \mathrm{~kg}$ $\mathrm{B}+4.0 \mathrm{~kg} \mathrm{Zn} / \mathrm{ha}$ and recommended dose of NPK, which was statistically similar with $2 \mathrm{~kg} \mathrm{~B}+4 \mathrm{~kg} \mathrm{Zn} / \mathrm{ha}$ and 50\% more than recommended dose of NPK $(19.27 \mathrm{~cm})$, whereas minimum $(16.50 \mathrm{~cm})$ was found from no boron $\&$ zinc and $50 \%$ less than the recommended dose of NPK and $0 \mathrm{~kg} \mathrm{~B}+0$ $\mathrm{kg} \mathrm{Zn} /$ ha and $50 \%$ more than recommended dose of NPK $(17.00 \mathrm{~cm})$ application and those were statistically equal (Table 4). Distinct variation was noted among the soil application of boron and zinc levels as to fruit girth (Table 2). It was ranged from $1.67 \mathrm{~cm}$ in $0 \mathrm{~kg} \mathrm{~B}+0 \mathrm{~kg} \mathrm{Zn} / \mathrm{ha}$ to 1.88 $\mathrm{cm}$ in with $2.0 \mathrm{~kg} \mathrm{~B}+4.0 \mathrm{~kg} \mathrm{Zn} /$ ha application. A similar trend was also observed regarding this parameter due to the effect of NPK as was evident in fruit length (Table 3). The highest fruit girth $(1.83 \mathrm{~cm})$ was recorded from the application of recommended dose of NPK, which was statistically same as treatment $50 \%$ more than the recommended dose of NPK $(1.79 \mathrm{~cm})$ and the lowest $(1.69$ $\mathrm{cm}$ ) was found from $50 \%$ less than the recommended dose of NPK application. There was significant variation among the combined application of boron, zinc and NPK in fruit girth (Table 4). Fruit girth was the highest $(1.96 \mathrm{~cm})$ in a combination of $2.0 \mathrm{~kg} \mathrm{~B}+4.0 \mathrm{~kg} \mathrm{Zn} / \mathrm{ha}$ and recommended dose of NPK statistically as same as $2.5 \mathrm{~kg} \mathrm{~B}+6 \mathrm{~kg} \mathrm{Zn} / \mathrm{ha}$ and recommended dose of NPK $(1.94 \mathrm{~cm})$ and the lowest $(1.60 \mathrm{~cm})$ was in no boron and zinc and $50 \%$ less than the recommended dose of NPK application (Table 4). 
Table 4. Combined effect of boron, zinc and NPK on yield contributing characters of okra seed.

\begin{tabular}{|c|c|c|c|c|c|c|c|}
\hline Treatment & $\begin{array}{l}\text { Plant height } \\
(\mathrm{cm})\end{array}$ & $\begin{array}{l}\text { No. of } \\
\text { fruits/plant }\end{array}$ & $\begin{array}{l}\text { Fruit length } \\
(\mathrm{cm})\end{array}$ & $\begin{array}{l}\text { Fruit girth } \\
\text { (cm) }\end{array}$ & $\begin{array}{l}\text { No. of } \\
\text { seeds/fruit }\end{array}$ & $\begin{array}{l}\text { 1000-seed wt. } \\
\text { (g.) }\end{array}$ & $\begin{array}{l}\text { Seed yield } \\
\text { (t/ha.) }\end{array}$ \\
\hline $\mathrm{B}_{0} \mathrm{Zn}_{0} \mathrm{NPK} 50 \%<\mathrm{RD}$ & $153.81 \mathrm{~g}$ & $17.50 \mathrm{~d}$ & $16.50 \mathrm{c}$ & $1.60 \mathrm{~d}$ & $51.45 \mathrm{e}$ & $58.00 \mathrm{~d}$ & $1.93 \mathrm{~g}$ \\
\hline $\mathrm{B}_{0} \mathrm{Zn}_{0} \mathrm{NPK} \mathrm{RD}$ & $160.51 \mathrm{fg}$ & $18.20 \mathrm{bcd}$ & $17.80 \mathrm{abc}$ & $1.70 \mathrm{bcd}$ & $52.50 \mathrm{de}$ & $58.50 \mathrm{~cd}$ & $2.06 \mathrm{f}$ \\
\hline $\mathrm{B}_{0} \mathrm{Zn}_{0} \mathrm{NPK} 50 \%>\mathrm{RD}$ & $164.45 \mathrm{efg}$ & $17.70 \mathrm{~cd}$ & $17.00 \mathrm{bc}$ & $1.70 \mathrm{bcd}$ & $51.60 \mathrm{e}$ & $58.20 \mathrm{~d}$ & $1.95 \mathrm{~g}$ \\
\hline $\mathrm{B}_{1.5} \mathrm{Zn}_{2.0} \mathrm{NPK} 50 \%<\mathrm{RD}$ & $168.50 \mathrm{def}$ & $18.34 \mathrm{bcd}$ & $17.70 \mathrm{abc}$ & $1.67 \mathrm{~cd}$ & $53.15 \mathrm{de}$ & $58.60 \mathrm{~cd}$ & $2.11 \mathrm{ef}$ \\
\hline $\mathrm{B}_{1.5} \mathrm{Zn}_{2.0} \mathrm{NPK} \mathrm{RD}$ & $178.21 \mathrm{abcd}$ & $18.50 \mathrm{bcd}$ & $18.75 \mathrm{ab}$ & $1.72 \mathrm{bcd}$ & $55.25 \mathrm{~cd}$ & $60.01 \mathrm{abc}$ & $2.26 \mathrm{~d}$ \\
\hline $\mathrm{B}_{1.5} \mathrm{Zn}_{2.0} \mathrm{NPK} 50 \%>\mathrm{RD}$ & $180.17 \mathrm{abcd}$ & $18.35 \mathrm{bcd}$ & $18.34 \mathrm{abc}$ & $1.70 \mathrm{bcd}$ & $54.20 \mathrm{de}$ & $59.31 \mathrm{bcd}$ & $2.17 \mathrm{de}$ \\
\hline $\mathrm{B}_{2.0} \mathrm{Zn}_{4.0} \mathrm{NPK} \mathrm{RD}$ & $186.40 \mathrm{ab}$ & $20.00 \mathrm{a}$ & $19.55 \mathrm{a}$ & $1.96 \mathrm{a}$ & $60.93 \mathrm{a}$ & $61.70 \mathrm{a}$ & $2.69 a$ \\
\hline $\mathrm{B}_{2.0} \mathrm{Zn}_{4.0} \mathrm{NPK} 50 \%>\mathrm{RD}$ & $184.12 \mathrm{abc}$ & $18.82 \mathrm{abcd}$ & $19.27 \mathrm{a}$ & $1.87 \mathrm{ab}$ & $58.00 \mathrm{abc}$ & $60.87 \mathrm{ab}$ & $2.44 \mathrm{c}$ \\
\hline $\mathrm{B}_{2.5} \mathrm{Zn}_{6.0} \mathrm{NPK} 50 \%<\mathrm{RD}$ & 173.10 cde & $18.82 \mathrm{abcd}$ & $18.30 \mathrm{abc}$ & $1.70 \mathrm{bcd}$ & $58.00 \mathrm{bc}$ & $60.50 \mathrm{ab}$ & $2.44 \mathrm{c}$ \\
\hline $\mathrm{B}_{2.5} \mathrm{Zn}_{6.0} \mathrm{NPK} \mathrm{RD}$ & $182.08 \mathrm{abc}$ & $19.50 \mathrm{ab}$ & $19.41 \mathrm{a}$ & $1.94 \mathrm{a}$ & $58.70 \mathrm{ab}$ & $61.11 \mathrm{a}$ & $2.58 \mathrm{~b}$ \\
\hline $\mathrm{B}_{2.5} \mathrm{Zn}_{6.0} \mathrm{NPK} 50 \%>\mathrm{RD}$ & $188.56 \mathrm{a}$ & $19.00 \mathrm{abc}$ & $19.20 \mathrm{a}$ & $1.90 \mathrm{a}$ & $57.67 \mathrm{bc}$ & $61.00 \mathrm{ab}$ & $2.48 \mathrm{bc}$ \\
\hline Level of significance & $* *$ & $* *$ & $* *$ & $*$ & $* *$ & $* *$ & $* *$ \\
\hline $\mathrm{CV}(\%)$ & 4.14 & 2.25 & 3.62 & 2.28 & 2.23 & 0.65 & 4.38 \\
\hline
\end{tabular}

Note: $\mathrm{B}_{0}=0 \mathrm{~kg}$ boron/ha, B $1.5=1.5 \mathrm{~kg}$ boron/ha, B $2.0=2 \mathrm{~kg}$ boron/ha, B $2.5=2.5 \mathrm{~kg}$ boron $/ \mathrm{ha}, \mathrm{Zn} 0=0 \mathrm{~kg}$ zinc/ha, Zn $2.0=2 \mathrm{~kg}$ zinc/ha, Zn $4.0=4 \mathrm{~kg}$ zinc/ha, Zn ${ }_{6.0}=6 \mathrm{~kg}$ zinc $/$ ha, NPK RD=Recommended dose of NPK fertilizers (Urea $=200 \mathrm{~kg}, \mathrm{TSP}=250 \mathrm{~kg}, \mathrm{MP}=150 \mathrm{~kg}$ ). In a column, the figures having a similar letter ( $\mathrm{s}$ ) do not differ significantly at 0.05 level of probability, ${ }^{* *}=$ Significant at 0.01 level, ${ }^{*}=$ Significant at 0.05 level

\subsection{Number of Seeds Per Fruit}

Different levels of boron and zinc application to soil showed wide variation in case of the number of filled seeds per fruit. The highest seeds per fruit (58.91) was found from $2.0 \mathrm{~kg} \mathrm{~B}+4.0 \mathrm{~kg} \mathrm{Zn} / \mathrm{ha}$, which was statistically similar with $2.0 \mathrm{~kg} \mathrm{~B}+6.0 \mathrm{~kg} \mathrm{Zn} / \mathrm{ha} \mathrm{(58.12)} \mathrm{and} \mathrm{the} \mathrm{lowest} \mathrm{seeds} \mathrm{per} \mathrm{fruit}$ (51.85) was found from treatment $0 \mathrm{~kg} \mathrm{~B}+0 \mathrm{~kg} \mathrm{Zn/ha} \mathrm{(Table}$ 2 ). Significant variation among the NPK levels was also observed in this aspect. It was as high as 56.85 in the recommended dose of NPK application and as low as 55.10 in $50 \%$ less than the recommended dose of NPK (Table 3 ). On the other hand, treatment combinations of boron, zinc and NPK significantly influenced the number of filled seeds per fruit. The maximum number of filled seeds per fruit (60.93) was noted from $2.0 \mathrm{~kg} \mathrm{~B}+4.0 \mathrm{~kg} \mathrm{Zn} / \mathrm{ha}$ and recommended dose of NPK, which was statistically similar with $2.5 \mathrm{~kg} \mathrm{~B}+$ $6.0 \mathrm{~kg} \mathrm{Zn} / \mathrm{ha}$ and recommended dose of NPK (58.70), whereas it was the lowest (51.45) with no boron, zinc and $50 \%$ less than the recommended dose of NPK and $0 \mathrm{~kg} \mathrm{~B}+0 \mathrm{~kg}$ $\mathrm{Zn} / \mathrm{ha}$ and $50 \%$ more than recommended dose of NPK (51.60) both were statistically similar (Table 4).

\subsection{0-seed Weight}

1000 -seed weight was influenced by different levels of boron and zinc application in the soil (Table 2). The highest 1000 -seed weight $(61.04 \mathrm{~g})$ was found from $2.0 \mathrm{~kg} \mathrm{~B}+4.0$ $\mathrm{kg} \mathrm{Zn} / \mathrm{ha}$, which was statistically at par with $2.5 \mathrm{~kg} \mathrm{~B}+6.0$ $\mathrm{kg} \mathrm{Zn} / \mathrm{ha}(60.87 \mathrm{~g})$ and the lowest $(58.23 \mathrm{~g})$ was found from no boron and zinc application. 1000-seed weight was also influenced by the main effect of NPK application. Maximum1000-seed weight $(60.33 \mathrm{~g})$ was recorded from recommended dose of NPK and 50\% more than the recommended dose of NPK (59.84 g), while the lowest (59.42 g) was recorded from 50\% less than the recommended dose of NPK application (Table 3). The combined treatment also influenced the 1000-seed weight. The highest 1000-seed weight $(61.70 \mathrm{~g})$ was noted from $2.0 \mathrm{~kg} \mathrm{~B}+4.0 \mathrm{~kg} \mathrm{Zn} / \mathrm{ha}$ and recommended dose of NPK, which was statistically equal with $2.5 \mathrm{~kg} \mathrm{~B}+6.0 \mathrm{~kg} \mathrm{Zn} / \mathrm{ha}$ and recommended dose of NPK $(61.11 \mathrm{~g})$ and the lowest $(58.00 \mathrm{~g})$ was recorded from $0 \mathrm{~kg} \mathrm{~B}$ $+0 \mathrm{~kg} \mathrm{Zn} / \mathrm{ha}$ and $50 \%$ less than the recommended dose of NPK, $0 \mathrm{~kg} \mathrm{~B}+0 \mathrm{~kg} \mathrm{Zn} / \mathrm{ha}$ and 50\% than the recommended dose of NPK $(58.20 \mathrm{~g})$ those were statistically at par (Table 4).

\subsection{Seed Yield Per Hectare}

Boron and zinc application influenced significantly on seed yield per hectare. The highest yield of seed per hectare $(2.52 \mathrm{t} / \mathrm{ha})$ was obtained from $2.0 \mathrm{~kg} \mathrm{~B}+4.0 \mathrm{~kg} \mathrm{Zn} / \mathrm{ha}$ treatment, which was statistically similar with treatment 2.5 $\mathrm{kg} \mathrm{B}+6.0 \mathrm{~kg} \mathrm{Zn} / \mathrm{ha}(2.50 \mathrm{t} / \mathrm{ha}$ ) (Table 2). NPK levels also significantly influenced the seed yield per hectare. The highest seed yield per hectare $(2.40 \mathrm{t} / \mathrm{ha})$ was recorded from recommended dose of NPK, whereas it was the lowest $(2.23$ $\mathrm{t} / \mathrm{ha}$ ) when $50 \%$ less than the recommended dose of NPK was applied (Table 3 ). There was significant variation among the treatment combinations in yield of seed per hectare. The highest seed yield per hectare $(2.69 \mathrm{t} / \mathrm{ha})$ was obtained from the combination of $2.0 \mathrm{~kg} \mathrm{~B}+4.0 \mathrm{~kg} \mathrm{Zn/ha}$ and recommended dose of NPK, whereas it was the lowest (1.93 t/ha) with $0 \mathrm{~kg} \mathrm{~B}+0 \mathrm{~kg} \mathrm{Zn} / \mathrm{ha}$ and $50 \%$ less than the recommended dose of NPK followed by $0 \mathrm{~kg} \mathrm{~B}+0 \mathrm{~kg} \mathrm{Zn} / \mathrm{ha}$ and $50 \%$ more than recommended dose of NPK $(1.95 \mathrm{t} / \mathrm{ha})$ application both were statistically equal (Table 4$)$.

\subsection{Germination and Seedling Vigour Index}

Seed germination was significantly influenced by different levels of boron and zinc application. The highest germination percentage (95.40\%) was observed with $2.0 \mathrm{~kg} \mathrm{~B}+4.0 \mathrm{~kg}$ $\mathrm{Zn} / \mathrm{ha}$ treatment, which was statistically at par with $2.5 \mathrm{~kg} \mathrm{~B}$ $+6 \mathrm{~kg} \mathrm{Zn} / \mathrm{ha}(94.60 \%)$ while it was the lowest $(80.21 \%)$ with no boron and zinc application (Table 5). The effect of NPK application on seed germination was also significant. It was 
ranged from $87.03 \%$ with $50 \%$ less than the recommended dose of NPK to $90.93 \%$ with the recommended dose of NPK application (Table 6). Seed germination was significantly influenced by the combined effect of boron, Zinc and NPK. The highest germination percentage $(97.00 \%)$ was obtained with $2.0 \mathrm{~kg} \mathrm{~B}+4.0 \mathrm{~kg} \mathrm{Zn} / \mathrm{ha}$ and recommended dose of NPK, which was statistically similar with $2 \mathrm{~kg} \mathrm{~B}+4 \mathrm{~kg} \mathrm{Zn/ha} \mathrm{and}$
$50 \%$ more than recommended dose of NPK $(96.00 \%), 2.5 \mathrm{~kg}$ $\mathrm{B}+6 \mathrm{~kg} \mathrm{Zn} / \mathrm{ha}$ and recommended dose of NPK (95.49\%), while the lowest $(78.50 \%)$ was recorded with $0 \mathrm{~kg} \mathrm{~B}+0 \mathrm{~kg}$ $\mathrm{Zn} / \mathrm{ha}$ and $50 \%$ less than the recommended dose of NPK followed by $0 \mathrm{~kg} \mathrm{~B}+0 \mathrm{~kg} \mathrm{Zn} / \mathrm{ha}$ and $50 \%$ more than recommended dose of NPK $(80.11 \%)$ application those were statistically equal (Table 7).

Table 5. Main effect of boron, zinc on quality contributing characters of okra seed.

\begin{tabular}{|c|c|c|c|c|c|}
\hline Treatment & Germination (\%) & Seedling vigour & Seed protein content (\%) & Seed boron content (ppm) & Seed $\mathrm{Zn}$ content $(\mathrm{ppm})$ \\
\hline $\mathrm{B}_{0} \mathrm{Zn}_{0}$ & $80.21 \mathrm{c}$ & $2039.04 \mathrm{c}$ & $17.33 \mathrm{c}$ & $32.03 \mathrm{~d}$ & $35.60 \mathrm{~d}$ \\
\hline $\mathrm{B}_{1.5} \mathrm{Zn}_{2.0}$ & $86.83 \mathrm{~b}$ & $2363.37 \mathrm{~b}$ & $18.95 b$ & $33.10 \mathrm{c}$ & $42.97 \mathrm{c}$ \\
\hline $\mathrm{B}_{2.0} \mathrm{Zn}_{4.0}$ & $95.40 \mathrm{a}$ & $2736.15 \mathrm{a}$ & $19.53 \mathrm{a}$ & $38.24 \mathrm{~b}$ & $45.33 \mathrm{~b}$ \\
\hline $\mathrm{B}_{2.5} \mathrm{Zn}_{6.0}$ & $94.60 \mathrm{a}$ & $2713.53 \mathrm{a}$ & $19.21 \mathrm{ab}$ & $40.10 \mathrm{a}$ & $47.96 \mathrm{a}$ \\
\hline Level of significance & $* *$ & $* *$ & $* *$ & $* *$ & $* *$ \\
\hline $\mathrm{CV}(\%)$ & 2.65 & 3.44 & 2.09 & 1.64 & 1.66 \\
\hline
\end{tabular}

Note: $\mathrm{B}_{0}=0 \mathrm{~kg}$ boron/ha, B $1.5=1.5 \mathrm{~kg}$ boron/ha, B $2.0=2 \mathrm{~kg}$ boron/ha, B $2.5=2.5 \mathrm{~kg}$ boron $/ \mathrm{ha}, \mathrm{Zn} 0=0 \mathrm{~kg}$ zinc/ha, Zn $2.0=2 \mathrm{~kg}$ zinc $/ \mathrm{ha}, \mathrm{Zn} 4.0=4 \mathrm{~kg}$ zinc $/ \mathrm{ha}, \mathrm{Zn}$ ${ }_{6.0}=6 \mathrm{~kg}$ zinc/ha.

Table 6. Main effect of NPK on quality contributing characters of okra seed.

\begin{tabular}{|c|c|c|c|c|c|}
\hline Treatment & Germination (\%) & Seedling vigour & Seed protein content (\%) & Seed boron content (ppm) & Seed $\mathrm{Zn}$ content (ppm) \\
\hline NPK50\% $<$ RD & $87.03 \mathrm{~b}$ & $2332.97 b$ & $18.41 \mathrm{~b}$ & $34.09 \mathrm{c}$ & $41.17 b$ \\
\hline NPK RD & $90.93 \mathrm{a}$ & $2562.93 \mathrm{a}$ & $19.29 \mathrm{a}$ & $36.09 \mathrm{~b}$ & $43.49 \mathrm{a}$ \\
\hline NPK $50 \%>R D$ & $89.81 \mathrm{ab}$ & $2493.17 \mathrm{ab}$ & $18.57 \mathrm{~b}$ & $37.44 \mathrm{a}$ & $44.24 \mathrm{a}$ \\
\hline Level of significance & $* *$ & $* *$ & $*$ & $* *$ & $* *$ \\
\hline $\mathrm{CV}(\%)$ & 2.65 & 3.44 & 2.09 & 1.64 & 1.66 \\
\hline
\end{tabular}

Note: NPK RD=Recommended dose of NPK fertilizers (Urea $=200 \mathrm{~kg}, \mathrm{TSP}=250 \mathrm{~kg}, \mathrm{MP}=150 \mathrm{~kg}$ ) In a column, the figures having similar letter ( $\mathrm{s}$ ) do not differ significantly at 0.05 level of probability, $* *=$ Significant at 0.01 level, $*=$ Significant at 0.05 level

Seedling vigour index was significantly influenced due to different levels of boron and zinc application. (Table 5). The highest vigourindex (2736.15) was obtained from the treatment $2.0 \mathrm{~kg} \mathrm{~B}+4.0 \mathrm{~kg} \mathrm{Zn} / \mathrm{ha}$ followed by $2.5 \mathrm{~kg} \mathrm{~B}+6$ $\mathrm{Zn} / \mathrm{ha}$ (2713.53) both were statistically similar. Different levels of NPK application had also significant effect on seedling vigour index. It was ranged from 2332.97 with $50 \%$ less than the recommended dose of NPK to 2562.93 with recommended dose of NPK (Table 6). A significant difference in seedling vigour index among the combination of boron, zinc and NPK was observed. The highest vigour index (2845.01) was recorded with the combined application of $2.0 \mathrm{~kg} \mathrm{~B}+4.0 \mathrm{~kg}$ $\mathrm{Zn} / \mathrm{ha}$ and recommended dose of NPK which was statistically similar with $2.0 \mathrm{~kg} \mathrm{~B}+4.0 \mathrm{~kg} \mathrm{Zn}$ and $50 \%$ more than recommended dose of NPK (2772.48) and the lowest reading (1953.86) was found with $0 \mathrm{~kg} \mathrm{~B}+0 \mathrm{~kg} \mathrm{Zn} / \mathrm{ha}$ and $50 \%$ less than the recommended dose of NPK followed by $0 \mathrm{~kg} \mathrm{~B}+0 \mathrm{~kg}$ $\mathrm{Zn} / \mathrm{ha}$ and $50 \%$ more than the recommended dose of NPK (2013.67) application both were statistical similar (Table 7).

Table 7. Combined effect of boron, zinc and NPK on quality contributing characters of okra seed.

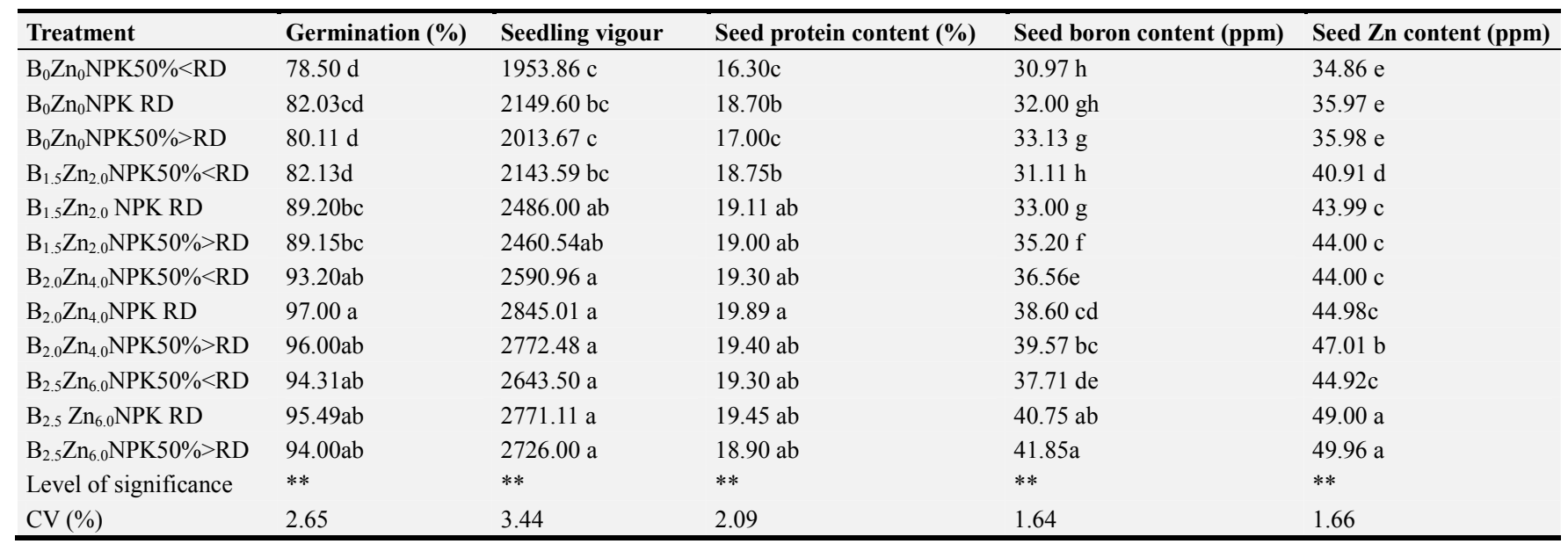

Note: $\mathrm{B}_{0}=0 \mathrm{~kg}$ boron/ha, B $1.5=1.5 \mathrm{~kg}$ boron/ha, B $2.0=2 \mathrm{~kg}$ boron/ha, B $2.5=2.5 \mathrm{~kg}$ boron $/ \mathrm{ha}, \mathrm{Zn} 0=0 \mathrm{~kg}$ zinc/ha, Zn $2.0=2 \mathrm{~kg}$ zinc $/ \mathrm{ha}, \mathrm{Zn}$ 4.0 $=4 \mathrm{~kg}$ zinc/ha, $\mathrm{Zn}$ ${ }_{6.0}=6 \mathrm{~kg}$ zinc $/ \mathrm{ha}$. NPK RD=Recommended dose of NPK fertilizers (Urea=200 kg, TSP=250 kg, MP=150 kg) In a column, the figures having similar letter (s) do not differ significantly at 0.05 level of probability, ${ }^{* *}=$ Significant at 0.01 level, $*=$ Significant at 0.05 level 


\subsection{Seed Protein Content}

Distinct variation was noticed in respect of protein content of seed due to the influence of boron and zinc application. The highest (19.53\%) seed protein content was found in $2 \mathrm{~kg}$ $\mathrm{B}+4 \mathrm{Zn} / \mathrm{ha}$ followed by $2.5 \mathrm{~kg} \mathrm{~B}+6 \mathrm{~kg} \mathrm{Zn} / \mathrm{ha}(19.21 \%)$ both were statistically equal and the lowest (17.33\%) protein content was observed in control (Table 5). NPK application also had a significant effect on the protein content of seed (Table 6). The highest protein content of seed (19.29\%) was recorded with the recommended dose of NPK and the lowest $(18.41 \%)$ was in $50 \%$ less than the recommended dose of NPK statistically as same as treatment $50 \%$ more than the recommended dose of NPK (18.57\%). Significant differences in protein content were found among the combined application of boron, zinc and NPK. The seed produced with $2.0 \mathrm{~kg} \mathrm{~B}+4.0 \mathrm{~kg} \mathrm{Zn} / \mathrm{ha}$ and recommended dose of NPK, had maximum protein content $(19.89 \%)$, which was statistically similar with $2.5 \mathrm{~kg} \mathrm{~B}+6.0 \mathrm{~kg} \mathrm{Zn}$ and the recommended dose of NPK (19.45\%) and it was minimum $(16.30 \%)$ in seeds produced with $0 \mathrm{~kg} \mathrm{~B}+0 \mathrm{~kg} \mathrm{Zn} / \mathrm{ha}$ and $50 \%$ less than the recommended dose of NPK followed by $0 \mathrm{~kg} \mathrm{~B}+0 \mathrm{~kg} \mathrm{Zn} / \mathrm{ha}$ and $50 \%$ more than the recommended dose of NPK (17.00\%) those were statistically equal (Table 7).

\subsection{Seed Boron Content}

Variation was observed in boron content of seed due to different levels of boron and zinc application. The highest seed boron content $(40.10 \mathrm{ppm})$ was recorded with the highest level of boron and zinc application $(2.5 \mathrm{~kg} \mathrm{~B}+6 \mathrm{~kg}$ $\mathrm{Zn} / \mathrm{ha})$, whereas it was the lowest (32.03 ppm) with no boron and zinc application (Table 5). Boron content of seed was also varied due to different levels of NPK application. It ranged from $34.09 \mathrm{ppm}$ to $37.44 \mathrm{ppm}$ (Table 6). The treatment combination also influenced the boron content of the seed. Maximum boron content (41.85 ppm) was observed in the treatment combination of $2.5 \mathrm{~kg} \mathrm{~B}+6.0 \mathrm{~kg} \mathrm{Zn} / \mathrm{ha}$ and $50 \%$ more than the recommended dose of NPK which was statistically at par with $2.5 \mathrm{~kg} \mathrm{~B}+6 \mathrm{~kg} \mathrm{Zn} / \mathrm{ha}$ and recommended dose of NPK (40.75 ppm) and minimum boron content (30.97 ppm) was found from $0 \mathrm{~kg} \mathrm{~B}+0 \mathrm{~kg} \mathrm{Zn} / \mathrm{ha}$ and $50 \%$ less than the recommended dose of NPK followed by $1.5 \mathrm{~kg} \mathrm{~B}+2 \mathrm{~kg} \mathrm{Zn} / \mathrm{ha}$ and $50 \%$ less than the recommended dose of NPK (31.11 ppm) application which was statistically similar (Table 7).

\subsection{Seed Zinc Content}

Significant difference was found in zinc content of seed due to the varied levels of boron and zinc application. The highest zinc content (47.96 ppm) was found in the treatment $2.5 \mathrm{~kg} \mathrm{~B}+6 \mathrm{~kg} \mathrm{Zn} / \mathrm{ha}$ and the lowest (35.60 ppm ) was in without boron and zinc application (Table 5). NPK application also influenced the zinc content of the seed. It ranged from $41.17 \mathrm{ppm}$ to $44.24 \mathrm{ppm}$ (Table 6). Significant variation was found among the treatment combinations in this respect. Maximum zinc content (49.96 ppm) was observed in seeds which were produced with $2.5 \mathrm{~kg} \mathrm{~B}+6.0$ $\mathrm{kg} \mathrm{Zn} / \mathrm{ha}$. and $50 \%$ more than the recommended dose of NPK, which was statistically as same as $2.5 \mathrm{~kg} \mathrm{~B}+6.0 \mathrm{~kg} \mathrm{Zn} / \mathrm{ha}$ and recommended dose of NPK (49.00 ppm), whereas it was minimum (34.86 ppm) in seeds produced with $0 \mathrm{~kg} \mathrm{~B}+0 \mathrm{~kg}$ $\mathrm{Zn} / \mathrm{ha}$ and $50 \%$ less than the recommended dose of NPK (Table 7).

\section{Discussion}

Application of boron and zinc influenced the plant height. It was increased with the higher level of boron and zinc fertilizer application. Boron and zinc might have played role in balanced absorption of nutrients, increased rate of photosynthesis and reduced transpiration. Davis et al. [28] reported that uptake of N, $\mathrm{K}, \mathrm{Mg}$ and $\mathrm{Ca}$ was increased with boron application. Dube et al. [29] found that plant highest was improved with the treatment combination of soil application of $10 \mathrm{~kg}$ zinc sulphate and $20 \mathrm{~kg}$ borax/ha in combination with foliar spray of $0.5 \%$ zinc sulphate and $0.3 \%$ borax. The highest plant height was observed with recommended doses of NPK. It might be due to the higher fertilizer levels helped to uptake higher amount of nutrients in the plants which enhanced chlorophyll content and carbohydrate synthesis was increased. So that the cell size was enlarged, rapid cell division was occurred and plant height was higher. The result is in agreement with Lenka et al. [30]. Boron and zinc application also influenced the number of fruit per plant significantly. It might probably boron and zinc improved pollen germination and pollen tube growth. Dugger and Humphreys [31] reported that boron was needed for the metabolism of sugar and that sugar borate complexes altered respiration and the biosynthesis of the pollen tube. This result is in agreement with Mashesh et al. [32]. Zinc also improved auxin production, flower and fruit setting and as a result number of fruit is increased. Higher doses of NPK influenced the number of fruit per plant. The higher dose of NPK was resulting in the greater synthesis of carbohydrate in the plant, which accelerates the fruit formation. Ahmed et al. [33] found a higher number of fruits per plant (24.59) in okra when applied at the rate of $120 \mathrm{~kg} \mathrm{~N}, 90 \mathrm{~kg}$ $\mathrm{P}$ and $60 \mathrm{~kg} \mathrm{~K} / \mathrm{ha}$. Combined application of boron and zinc had significant effect on fruit length of okra. Fruit length was increased with increasing level of boron and zinc application [34]. There was a significant difference among the levels of boron and zinc application in the number of seeds per fruit. The higher number of filled seeds per fruit was recorded from $2 \mathrm{~kg}$ $\mathrm{B} / \mathrm{ha}$ and $4 \mathrm{~kg} \mathrm{Zn} / \mathrm{ha}$. This result is also in conformity with the work of Shruti and Chauhan [35]. Distinct variation among the NPK levels was also significant in this aspect, where lower number of seeds was found in $50 \%$ less than the recommended dose of NPK and higher was in the recommended dose of NPK. On the other hand, treatment combinations of boron, zinc and NPK significantly influenced the number of filled seeds per fruit. Prasad et al. [36] reported that application of $80 \mathrm{~kg} / \mathrm{ha} \mathrm{P}_{2} \mathrm{O}_{5}$ along with $120 \mathrm{~kg} / \mathrm{ha} \mathrm{N}$ provided the highest number of seeds 
(57) per fruit in okra cv. Parbhanikranti. The present results partially corroborate with their findings.

In the present experiment, the highest 1000 seed weight was found through the application of born, zinc and NPK singly as well as their combination. Boron plays a significant role in development and growth of new cells in the plant meristem, pollination, fruit set and seeds formation, movement of nitrogen, phosphorus, starches, etc in different crops [37]. Zinc increases photosynthesis and translocation of food materials. Seed weight was higher might be due to better mineral utilization of plants accompanied by enhancement of photosynthesis, other metabolic activity and greater diversion of food material to seed [38]. This result is in agreement with Shruti and Chauhan [35]. Seed yield was increased may be due to the increase number of fruit, number of seed per fruit and seed weight per fruit. NPK dose play more role in vegetative growth than the reproductive phase and better pollen germination resulting in increased fruit set. Boron and zinc increased the photosynthetic rate and translocation of food material to seed resulting increased number of seeds per fruit and seed weight per fruit. This result is in accordance with the findings of Patil et al. [39], Bhat and Dhar [40], Sultana [41] and Dixit [42].

Seed germination percentage was significantly improved with the increasing levels of boron and zinc up to $2.5 \mathrm{~kg} \mathrm{~B} / \mathrm{ha}$ $+6 \mathrm{~kg} \mathrm{Zn} /$ haalong with the recommended dose of NPK. It may be boron acts for carbohydrate metabolism, cell division, protein formation, keeps pollen healthy and viable, helps seed production and prevents sterility of seed. Zinc increases protein synthysis which increased seed germination.

A similar result was found by Manivasagaperumal et al. [43]. Seedling vigor index was significantly influenced due to boron and zinc application. The highest vigour index (2736.15) was obtained from $2.0 \mathrm{~kg} \mathrm{~B}+4.0 \mathrm{~kg} \mathrm{Zn} / \mathrm{ha}$ as well as the combined application of $2.0 \mathrm{~kg} \mathrm{~B}+4.0 \mathrm{~kg} \mathrm{Zn} / \mathrm{ha}$ and recommended dose of NPK.

A similar observation was reported by Kiran [44]. It has been reported that application of boron and zinc either in soil or foliar can effect on protein, boron and zinc content of okra seed $[45,46]$. However, in this studies single or combined doses were investigated on the yield and quality of okra seed. Overall fruit characters, yield and quality of seed were positively influenced by combined application of boron, zinc and NPK. The combination of $2 \mathrm{~kg} \mathrm{~B}$ and $4 \mathrm{~kg} \mathrm{Zn} / \mathrm{ha}$, along with the recommended dose of NPK can help to achieve the maximum productivity and quality of okra seed.

\section{Conclusion}

From the results of the investigation it may be concluded that selected combination of boron and zinc alone with recommended dose of NPK fertilizers demonstrated better results in respect of yield and quality of okra seed. High yield and good quality of okra seed can be obtained with the application of $2 \mathrm{~kg}$ boron/ha and $4 \mathrm{~kg}$ Zinc/ha in combination with recommended dose of NPK fertilizers.

\section{References}

[1] Ahmad, K. U. (1995). Phul-phal O Shak-Shabji (in Bangla) Fifth edition. M. Momtaj Kamal. Mirpur, Dhaka, Bangladesh. pp. 353.

[2] Ishaque, M. (1976). Nutritive value of fruits and vegetables. A Bulletin of Horticultural Development Board. Horticultural Development Board, Dhaka. pp. 5-15.

[3] Adelakun O. E.; Oyelade O. J.; Ade-Omowaye B. I. O.; Adeyemi I. A. and Van-de-Venter M. (2009). Chemical composition and the ant oxidative properties of Nigerian Okra seed (Abelmoschusesculentus Moench) flour. Food Chem. Toxicol. 47 (6): 1123-1126. DOI: 10.1016/j.fct.2009.01.036.

[4] Mew, T. W. (1997). Seed health testing: Progress towards $21^{\text {st }}$ Century. In: Huthins and Ruces (Editors), Development of rice seed health testing policy. pp. 129-138.

[5] Kanwar, H. S. (2017). Advances in quality seed production of vegetable crops. Training manual, Centre of advanced faculty training in horticulture (vegetables), Department of vegetable science, YSP University of Horticulture and Forestry Nauni 173230 Solan, Himachal Pradesh, India.

[6] George, R. A. T. 1985. Vegetable Seed Production. John Willy and Sons, 605, Third Avenue, New York. pp. 318.

[7] Islam, M. S. (2008). Soil fertility history, present status and future scenario in Bangladesh. Bangladesh Journal of Agriculture and Environment. 4: 129-151.

[8] Khanam, R.; Arefin, M. S.; Haque, M. A.; Islam, M. R. and Jahiruddin, M. (2000). Effects of magnesium, boronand molybdenum on the growth, yield and protein content of chickpea and lentil. Progressive Agriculture. 11 (1 \& 2): 7780 .

[9] Bhuiyan, M. A. H.; Khanam, D.; Khatun, M. R. and Hassan, M. S. (1998). Effects of molybdenum, boron and Rhizobium on nodulation, growth and yield of chickpea, Bulletin Institute of Tropical Agriculture Kyushu University, 21, 1-7.

[10] Jahan, N., Hoque, M. A., Monir, M. R., Fatima, S., Islam, M. $\mathrm{N}$ and Hossain, M. B. 2020. Effect of Zinc and Boron on Growth and Yield of Okra (AbelmoschusesculentusL.). Asian Journal of Advances in Agricultural Research. 12 (1): 41-47. DOI: 10.9734/AJAAR/2020/v12i130073

[11] Singh, A. K.; Khan, M. A. and Srivastava, A. (2014). Effect of boron and molybdenum application on seed yield of mung bean. Asian Journal of Biolological Science. 9: 169-172. DOI: 10.15740/HAS/AJBS/9.2/169-172.

[12] Agarwala, S. C., Sharma, P. N., Chatterjee, C. and Sharma, C. P. (1981). Development and enzymatic change during pollen development in boron deficiency maize plants. Journal of $\begin{array}{lll}\text { Plant } & \text { Nutrition. 32 } & \text { 329-336. }\end{array}$ doi.org/10.1080/01904168109362841.

[13] Birch, E. B. (1981). Some factors affecting seed set of sunflower. Crop Production. 10: 22-26.

[14] Walker, W. M.; Graffis, D. W. and Faulkner, C. D. (1987). Effect of potassium and boron upon yield and nutrient concentration of Alfalfa. Jurnal ofPlant Nutrition. 10: 21692180.doi.org/10.1080/01904168709363770. 
[15] Katyal, J. C. and Randhawa N. S. (1983). Micronutrients. FAO Fertilizer and Plant Nutrition Bulletin. pp. 3-76.

[16] Ali, A.; Ahmad, B.; Hussain, I.; Ali, A. and Ali Shah, F. (2017). Effect of phosphorus and zinc on yield of lentil. Pure and Applied Biology. 6 (4): 1397-1402. http://dx.doi.org/10.19045/bspab.2017.600150.

[17] Jayaweera, G. R. and Mikkelsen, D. S. (1991). Assessment of ammonia volatilization from flooded soil systems. Advances in Agronomy. 45: 303-353. DOI: 10.1016/S00652113(08)60044-9.

[18] Ginindza, T. K., Masarirambi, M. T., Wahome, P. K. and Oseni, T. O. (2015). Effects of different concentrations of NPK fertilizers on growth and development of wild okra (Corchorusolitorius). Agriculture and Biology Journal of $\begin{array}{llll}\text { North America. } 6 & \text { (3): 74-80. DOI: }\end{array}$ 10.5251/abjna.2015.6.3.74.80.

[19] Mandal, P. N., Singh, K. P., Singh, V. K. and Roy, R. K. (2012). Effect of production and plant growth regulators on quality and economics of hybrid okra (Abelmoschusesculentus (L.) Moench), Advance Research Journal of Crop improvement. 3: 5-7.

[20] Huq, S. M. I. and Shoaib J. U. M. (2013). The Soils of Bangladesh, World Soils Book Series 1, Springer Science.

[21] FRG (Fertilizer Recommendation Guide). (2005). Fertilizer Recommendation Guide. Bangladesh Agricultural Research Council, Farmgate, Dhaka, Bangladesh.

[22] Agrawal, R. L. (1996). Seed Technology. Oxford \& IBH, New Delhi-110001, India. pp. 829.

[23] Abdul-Baki, A. A.; Anderson, J. D. (1973). Physiological and biochemical deterioration of seed. In: T. T. Kozlowski (Editor), Seed Biology, Vol-II, Academic Press, New York, London. pp. 283-315.

[24] Lowery, O. H, Rosen rough, N. R. J, Far, A. L, Randil, R. J. (1951). Protein measurement with the folin phenol reagent. Journal of Biological Chemistry. 193: 265-275. PMID: 14907713.

[25] Hunter, A. H. (1980). Soil Fertility Analytical Service in Bangladesh. Consultancy Report. BJRI Project Phase II, BARC, Dhaka, Bangladesh. pp. 53.

[26] Rahayu, Y. S; Romheld, V.; Bangerth, F.; Neilsen, D.; Fallahi, B.; Neilsen, G and Peryea, F. (2001). Does zinc nutrition affect calcium disorder of fruits. ActaHorticulturae. 564: 135143. DOI: 10.17660/ActaHortic.2001.564.15.

[27] Gomez, A. K. and Gomez, A. A. (1984). Statistical Procedures for Agricultural Research. Second edition, John Wiley and Sons. New York. USA. pp. 200-215.

[28] Davis, J. M., Douglas, C. S., Paul, V. N., Laura, L. and Wade. J. S. (2003). Boron improved growth, yield, quality and nutrient content of tomato. J. Amer. Soc. Hort. Sci. 128 (3): 441-446.

[29] Dube, K., Pratima, S. and Chatterjee, C. (2003). Effect of zinc on the yield and quality of tomato. Indian Journal of Horticulture. 60 (1): 59-63.

[30] Lenka, P. C, Das, D. K. and Mishra, H. N. (1989). Effect of nitrogen and phosphorus on seed yield of bhindi cv. Parbhanikranti. Orissa Journal of Agricultural Research. 2 (2):
$125-127$.

[31] Dugger. W. M. JR. and Humphreys. T. E. (1960). Influence of boron on enzymatic reaction associated with biosynthesis of sucrose. Plant Physiology. 35: 523-530. DOI: https://doi.org/10.1104/pp.35.4.523.

[32] Mahesh, K. and Sen, N. L. (2004). Interaction effect of zinc and boron on okra (Abelmoschusesculentus L. Moench) cv. Prabhani Kranti. Agricultural Science Digest. 24 (4): 307-308.

[33] Ahmed, N. and Tanki, M. I. (1997). Effects of nitrogen and phosphorus on growth and seed yield of okra. Indian Journal of Horticulture. 54 (2): 156-159.

[34] Muhammad, A. B., Abdul, Q. G., Muhammad, I. J., Tariq, A., Sher, A., Mohammad, I. M., Muhammad, S., Javed, A. A, and Syed, I. A. S. (2019). Response of okra verities, to zinc and boron supplement under the agro-climatic condition of Tandojam- Pakistan. Pure and Applied Biology. 8 (1): 601608. http://dx.doi.org/10.19045/bspab.2018.700222.

[35] Shruti, B., Chauhan, S. V. S. (2001). Effect of zinc, boron and manganese on yield in okra (Abelmoschusesculentus). Indian journal of Agricultural Sciences. 71 (5): 332-333.

[36] Prasadi, Y., Singh, G., Prasadi, Y. and Shingh, G. (2001). Effects of nutrition and time of sowing on growth and seed production of okra (Abelmoschusesculentus L. Moench) cv. Parbhanikranti. IAVS - Publications: Vegetation Science. 28 (2): 186-187.

[37] Lewis, D. H. (1980). Boron lignifications and the origin of vascular plants - a united hypothesis. New Phytol. 84: 209229 .

[38] Naga, S. K., Swain, S. K, Raju, B. and Sandeep, V. V. (2013). Effect of micronutrients foliar application on seed yield in tomato (Lycopersiconesculentummill). International Journal of Plant and Animal Science. 1 (7): 70-72.

[39] Patil, R. V., Kolase, S. V. andKadam, K. G. (2007). Effect of micronutrients on seed production in okra. Ecology, Environment \& Conservation. 13 (4): 829-830.

[40] Bhat, K. L, and Dhar, R. K. (1999). Effect of nitrogen and phosphorus on seed yield of okra (Abelmoschusesculentus L. Moench). Journal of Vegetation Science. 26 (1): 89-90.

[41] Sultana, S. (2002). Effect of nitrogen, phosphorus, potassium, sulphur and boron on okra. M. S Thesis. Department of Soil Science, Banghabandhu Sheikh Muijibur Rahman Agril. Univ., Gazipur.

[42] Dixit, S. P. (1997). Response of onion (Allium cepaL.) to nitrogen and farmyard manure in dry temperate high hills of Himachal Pradesh. Indian Journal of Agricultural Sciences. 67 (5): 222-223.

[43] Manivasagaperumal, R., Balamurugan, S., Thiyagarajan, G. and Sekar, J. (2011). Effect of zinc on germination, seedling growth and biochemical content of cluster bean (CyamopsistetragonolobaL. Taub). Current Botany. 2 (5): 1115.

[44] Kiran, J. (2006). Effect of fertilizer, biofertilizer and micronutrients on seed yield and quality of brinjal (SolanummelongenaL.). MS thesis, department of seed science and technology, college of agriculture, dharwaduniversity of agricultural sciences, dharwad, India. 
[45] Rahman, M. H, Hossain, I, Ahmad, M. U. and Rahim, M. A. (2017). Effects of boron and zinc on yield and quality of okra seed. Advances in Bioresearch. 8 (1): 202-211 DOI: 10.15515/abr.0976-4585.8.1.202211.
[46] Sarkar, R. K., J. C. Jana and Datta. S. (2017). Effect of boron and zinc application on growth, seed yield and seed quality of water spinach (Ipomoea reptans Poir.) under terai region of West Bengal. Journal of Applied and Natural Science. 9 (3): 1696-1702. 